\title{
ORMOSOLENIA RESTORED
}

\author{
MICHAEL G. PIMENOV*
}

\begin{abstract}
Ormosolenia Tausch is shown to be a separate monotypic genus of the Umbelliferae, distinct from Peucedanum L. A new combination, $O$. alpina (Sieber ex Schultes) M. Pimenov is proposed for the only species of the genus which is endemic to the eastem part of the Mediterranean.
\end{abstract}

A beautiful high-mountain scree species from the family Umbelliferae inhabits the mountains of Crete and the adjacent part of Asia Minor. It is remarkable not only for its life-form, creeping among stones, and its few-rayed umbels (a feature of high-mountain species of this family), but especially for the form of its leaves. These are usually simple, reniform with deeply crenate margins though sometimes they can be ternate or even pinnate: in such cases the upper leaflet has the shape described above and is much larger than the lateral leaflets. This combination of habit and leaf-form is unknown in other Mediterranean species of the Umbelliferae.

The species was first described in 1820 by J.A. Schultes under the name Sison alpinus Sieber ex Schultes although this initial assignment of the species to the genus Sison was made with some degree of doubt. The following year Sprengel treated the species as Peucedanum creticum but it was left to Tausch in 1834 to transfer it to his new genus Ormosolenia as $O$. cretica. Edmond Boissier added a second species, $O$. pisidica, in 1849 but in his Flora Orientalis of 1872 he treated both taxa as Peucedanum. This has been followed by subsequent authors: Burtt \& Davis (1949) corrected the specific epithet to $P$. alpinum but maintained both species, to be united later by Chamberlain (1972: 479) dealing with much richer material.

The genus Peucedanum as it is usually regarded in current literature is undoubtedly a complex, artificial taxon. It is a core genus of the tribe Peucedaneae and, as is sometimes the case with other traditional core genera in the Umbelliferae (and also in Compositae e.g. Senecio), contains groups of species, not themselves closely related. It comprises a large and very heterogeneous assemblage of species with dorsally compressed fruits and a few other common morphological characters. These species are spread over a very large area in Europe, Asia and Africa though no part of these could be regarded as a centre of origin of the genus. Attempts to split Peucedanum into natural groups have been repeatedly undertaken since Schur in 1866 but a very broad concept of the genus still predominates.

The situation with $P$. alpinum is typical of similar problems connected with the revision of the genus Peucedanum. $P$. alpinum belongs to one of several peripheral groups, not closely related to the type section and type species of Peucedanum, $P$.

* Botanical Garden, Biological Faculty, Moscow State University, Moscow, Russia. 
officinale. This, as well as some closely related species of the type section, is a tall erect herb (60-200 cm high) with a thick rootstock crowned with fibrous remains, \pm leafy stems, leaves 2-6-ternate with linear or filiform lobes and 10-40 rays to the umbel; all grow usually in grassland habitats. $P$. alpinum, on the other hand, is a small plant found creeping on screes; it has aphyllous stems, radical ternate or simple reniform leaves and $3-4(-6)$-rayed umbels. The only common character is the dorsal flattening of the fruit, without prominent dorsal ribs and with winged marginal ones. Fruits of this type are well adapted for dispersal by wind and occur rather frequently in the Umbelliferae. In my opinion a similarity in outer fruit form alone is insufficient for assigning species of the Umbelliferae to the same genus if they differ in many other characters. Moreover the fruits can differ in their inner structure while their outer form appears similar. The fruit structure of $P$. alpinum has hitherto been little known, the available information being limited to Boissier's description: ' ... fructu pedicello non incrassato breviore elliptico convexiusculo margine semine sextuplo angustiore cincto, jugis vix prominulis, valleculis 2-3-vittatis, commissurae flexuose sexvittatae' (Boissier, 1872: 1022). I have now studied the anatomical structure of the fruit of $P$. alpinum comparing it with that of $P$. officinale.

The mericarps of $P$. alpinum (Fig. 1) are compressed dorsally, with the marginal ribs narrowly winged and the dorsal ones virtually absent, their position being determined by the position of the vascular bundles. The exocarp is of one layer, interrupted near the ends of the marginal ribs and consisting of small cells each isodiametric or slightly elongated radially. The mesocarp is two layered, its outer layer consisting of parenchymatic cells with thin walls. Within the marginal ribs some of these cells have slightly thickened, insignificantly lignified walls with chinked pores. The inner layer of mesocarp consists of 3-5 rows of prosenchymatic cells which are elongated tangentially and have slightly lignified walls with clearly distinguishable chinked pores. The vascular bundles are small, in mature fruits their histological elements are hardly distinguishable. The oil ducts are situated in the outer layer of the mesocarp near its border with the inner layer, dorsally 3-6 per vallecula but sometimes also under the vascular bundles. Extrafascicular ducts can also be observed in some ribs on the dorsal side though they are apparently short and cannot be observed in all ribs in one cross-section. On the commissural side of the mericarps there are 6-8 ducts. The endocarp is of one layer, the seed coat in the mature fruits is compressed and deformed. The endosperm is flat on the ventral side.

The differences between the anatomical structure of the fruit of this species and of $P$. officinale prove to be considerable (the absence of conspicuous dorsal ribs, the existence of the inner layer of the mesocarp consisting of prosenchymatic cells, the arrangement of the oil ducts, etc.).

A complete revision of Peucedanum s.l. does not seem to be feasible in the near future because it requires a precise comparison of more than 200 described taxa as well as a determined search of valid and appropriate names in the Augean stables of Peucedanum nomenclature. Nevertheless the gradual separation of small natural groups should be realized in preparation for such a revision. It is quite clear that Peucedanum s. str. is one 

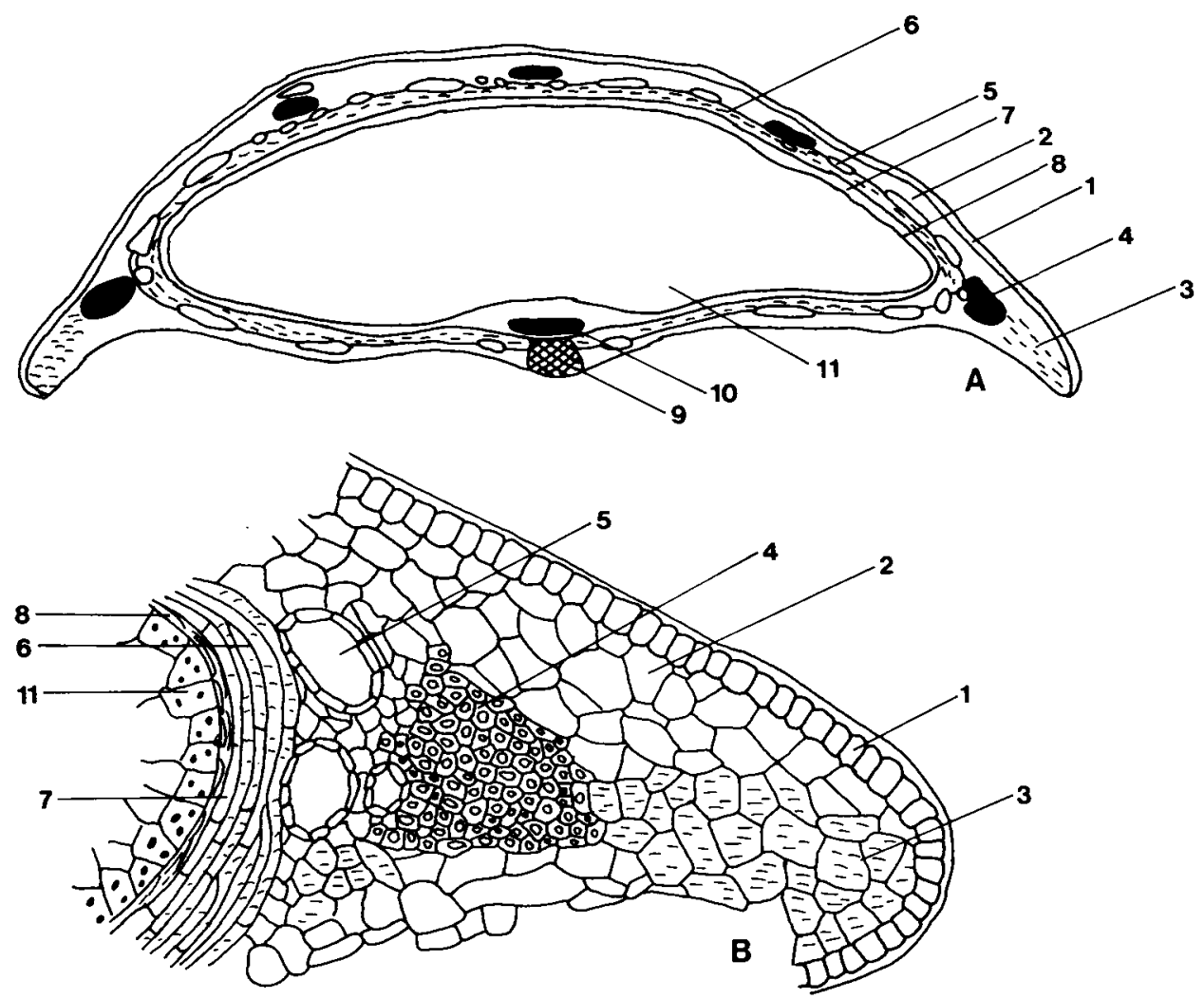

FIG. 1. Ormosolenia alpina. A, TS of mericarp, schematic; B, TS of mericarp in region of marginal rib. 1 , exocarp; 2 , parenchyma of mesocarp; 3 , cells with lignified walls; 4 , vascular bundle; 5 , oil duct; 6 , inner layer of mesocarp; 7, endocarp; 8 , seed coat; 9 , sclerenchyma of commissure; 10 , vascular bundle of funicle; 11 , endosperm.

of these small natural genera, made up mainly of Mediterranean, European and West Asiatic species. Similar equivalent taxa likely to be designated in the future will be geographically rather limited. Many such taxa will probably be monotypic, and in such cases it would be desirable to compare critical taxa with some allopatric or geographically related species attributed to Peucedanum s.l. An obvious character of $P$. alpinum is its leafless stem: the only two other Peucedanum species without cauline leaves in this region are $P$. lavrentiadis Strid \& Papanicolau (1980) and $P$. stridii Hartvig (1986), the latter being originally described as a subspecies (subsp. multicaulis Strid \& Papanicolau) of the former (Strid \& Papanicolau, 1980). The species under review and these two closely related ones differ considerably. As was noted in the protologue of $P$. lavrentiadis, $P$. alpinum 'differs in a number of important characters, however, and must be placed in a different section of the genus'. The most important distinctive features seem to be the structure of the secretory system in the fruit (solitary vallecular oil ducts in $P$. lavrentiadis, 3-6 per vallecula in $P$. alpinum) and the pattern of leaf dissection; of 
less importance are compact as against sparse umbels and the degree of prominence of the dorsal ribs of the mericarps.

The above results lead me to conclude that it is worthwhile restoring Ormosolenia as a separate genus distinct from Peucedanum. However, the question of whether the two are closely related or not still remains to be solved. Burtt \& Davis (1949) have suggested an affinity between $P$. alpinum and Glaucosciadium while in some characters of fruit histology (e.g. the inner layer of mesocarp consisting of prosenchymatic cells with chinked pores) it is similar to the genera in the tribe Tordylieae Koch.

Ormosolenia, for which an expanded description is given, is a monotypic genus, endemic to the eastern part of the Mediterranean.

\section{Ormosolenia Tausch}

Plantae perennes, glaucae, humiles, caudicibus ramosis, caulibus aphyllis vel subaphyllis, procumbentibus vel adscendentibus. Folia basalia laminis simplicibus ambitu reniformibus vel pinnatis, segmentis terminalibus majoribus, reniformibus vel orbicularibus, segmentis lateralibus 1-2-jugis, minoribus, profunde dissectis. Umbellae pauciradiatae, involucris nullis. Umbellulae paucipedicellatae, bracteolis nullis vel 1-2 setaceis. Dentes calycini obsoleti. Petala viridi-flava vel brunea, apice incurva et attenuata. Fructus dorso compressi; stylopodium plano-conicum margine vix undulatis, stylodiis brevibus, dorso reflexis, mericarpiis jugis dorsalibus inconspicuis, marginalibus anguste alatis. Exocarpium unistratosum, e cellulis minutis, ad extremitatem distalem jugorum interruptum. Mesocarpium bistratosum: stratum externum e cellulis parenchymaticis, partim membranis vix lignescentibus fissuratim porosis, stratum internum e cellulis prosenchymaticis, tangentaliter elongatis, fissuratim porosis compositum. Vittae minores valleculares 3-6, a latere commissurali 6-8. Endospermium ventre planum.

Typus generis et species unica: $O$. alpina (Sieber ex Schultes) M. Pimenov.

O. alpina (Sieber ex Schultes) M. Pimenov, comb. nov.

Syn.: Sison ? alpinus Sieber ex Schultes in Roemer \& Schultes, Syst.

Veget. 6: 414 (1820). Type: [Crete] 'in altissimis montium

Sphakiott', Sieber (n.v.).

Peucedanum creticum Sprengel, Neue Entd. 2: 148 (1821) nom.

illegit. (Art. 63.1); Rech. f. in Fl. Aegaea: 413 (1943). Type: as

for Sison alpinus.

Sison ? sieberianum DC., Prodr. 4: 111 (1830).

Ormosolenia cretica (Sprengel) Tausch in Flora 17: 348 (1834), nom. illegit.

O. pisidica Boiss. \& Heldr. in Boiss. Diagn. ser. 1, 10: 34 (1849).

Type: [Turkey]'Hab. inter lapides in regione alpina montis

Stavros Pisidiae prope Isbarta alt 6500ft' Heldreich. G.

Peucedanum pisidicum (Boiss. \& Heldr.) Boiss. in Fl. Orient. 2:

1021 (1872). 
P. alpinum (Sieber et Schultes) Burtt \& Davis in Kew Bull.: 227 (1949); Tutin in Fl. Eur. 2: 364 (1968); Chamberlain in P.H. Davis, Fl. Turkey 4: 479 (1972).

Ic.: F.W. Sieber, Reise nach Kreta, t. 7 (1823) as Sison alpinum. Distribution:

CRETE: in altissimis montium Sphakiott, Sieber (n.v.); Creta, inter lapides, vii. 1846, Heldreich (LE); Ep. Sfakia, in jugo ad meridiem cistemae Stemes montium alborum, $2050 \mathrm{~m}$, in glareosis mobilibus, 20 ix 1966, W. Greuter 7551 (G, E); White Mts, Svourichti, 2200$2300 \mathrm{~m}, 4$ viii 1950, PH. Davis 18126 (E); White Mts, summit of the Mt Pnevma, 19 viii 1971, A.C. Jermy \& P.J. Brownsey 9157 (BM); Ep. Sfakia, sdl. am Gipfel ralimni ol des Berges Trocharis, $2100-2150 \mathrm{~m}$, Trihalitsa-Kall, 1 vii 1962,W. Greuter 4833 (G); in glareosis calc. montii Paches, c. $2300 \mathrm{~m}$ (distr. Sphakia, Levka Ori), 16 vi 1942, KH. Rechinger 13848 (G); in summis Mt Sphakioticis, alt. 7000ft, vi 1846, Heldreich (E, BM); Mt Sphakia, vi 1932, Guiol 2151 (BM); inter lapides summi Mt Stravopodia, 7000ft, vi 1846, Heldreich (BM, G). TURKEY: Prov. Antalya: in regione alpina montis Stavros Pisidiae prope Isbarta [Isparta], $6500 \mathrm{ft}$, Heldreich (G); distr. Elmali, Bey Dagh, 2500m, 28 vii 1960, Khan, Prance \& Ratcliffe 282 (E); vil. Antalya, Takhtali Dagh (Kemer), 2100m, 16 viii 1947, P.H. Davis 14196 (E, G, K); distr. Kemer, Takhtali Dagh, 10 vii 1949, P.H. Davis 15069 (E, K).

\section{REFERENCES}

BOISSIER, E. (1849). Diagnoses plantarum orientalium novarum. Ser. 1 (10): 1 - 122. Geneva.

BoIsSIER, E. (1872). Flora Orientalis 2: 1016-1026. Geneva \& Basel.

BURTT, B.L. \& DAVIS, P.H. (1949). Glaucosciadium a new Mediterranean genus of Umbelliferae. Kew Bull. 1949: 225-230.

Chamberlain, D.F. (1972). Peucedanum L. - in P.H. Davis, Flora of Turkey and the East Aegean Islands 4: 473-481. Edinburgh.

Hartvig, P. (1986). Peucedanum L. - in A. STRID, Mountain Flora of Greece 1: 714-722. Copenhagen.

SCHUR, F. (1866). Enumeratio plantarum Transsilvaniae. Vienna.

STRID, A. \& PaPanicolau, K. (1980). New species of Aethionema and Peucedanum from the Greek mountains. Bot. Not. 133: 521-526.

Tutin, T.G. (1968). Peucedanum L. - in TUTN et al., Flora Europaea 2: 360-364. Cambridge. 